\title{
The Need for Quinean Pragmatism in the Theory of History
}

Jonathan Gorman

\section{(2) OpenEdition}

\section{Journals}

Electronic version

URL: http://journals.openedition.org/ejpap/645

DOI: $10.4000 /$ ejpap. 645

ISSN: 2036-4091

\section{Publisher}

Associazione Pragma

Electronic reference

Jonathan Gorman, «The Need for Quinean Pragmatism in the Theory of History », European Journal of Pragmatism and American Philosophy [Online], VIII-2 | 2016, Online since 16 January 2017, connection on 20 April 2019. URL : http://journals.openedition.org/ejpap/645; DOI : 10.4000/ejpap.645

This text was automatically generated on 20 April 2019.

\section{(c) $\Theta \Theta \Theta$}

Author retains copyright and grants the European Journal of Pragmatism and American Philosophy right of first publication with the work simultaneously licensed under a Creative Commons AttributionNonCommercial-NoDerivatives 4.0 International License. 


\title{
The Need for Quinean Pragmatism in the Theory of History
}

\author{
Jonathan Gorman
}

\section{Historical and Philosophical Stances}

1 Suppose we speculated that there was some connection between pragmatism and philosophical theorising about history. How might we investigate whether that was so? A claim that there was some such connection might be interpretable as a factual if vague assertion that pragmatists share an interest in philosophical theorising about history. Given this, and seeking more exactness, we might well need first to identify our "pragmatists": pragmatism has a long and complex tradition that has been expressed in multifarious, even inconsistent, ways, and we might well find that only some pragmatists have, or have had, this interest. Perhaps we would find ourselves addressing the interests only of some past - to be clear, historical - pragmatists; perhaps only some present ones; perhaps, indeed, all, regardless of date. Yet even if only present-day pragmatists were involved and the imagined factual claim (about their interest in philosophical theorising about history) were expressed in the present tense, this assertion would nevertheless, not at all implausibly, be warranted by historical methods, that is, warranted by informed and scholarly reading of relevant texts and other interpretable remains.

While it is true that such methods are commonly, even necessarily, used in historical research, the reference here to "historical methods," and the particular characterisation of them just mentioned, might suggest that we here presuppose the view that "history" should be conceived, even exhaustively conceived, as a particular kind of epistemic discipline. Yet how "history" should be conceived is a controversial part of what "philosophical theorising about history" involves. Philosophical readers might well be suspicious that the view that history is an epistemic discipline would itself be an outcome of philosophical theorising about history, and was not a conclusion to be taken for granted. They would be right, on both counts. However, while it is appropriate to be alert to such matters, we do not yet need to determine or presuppose any connection with 
theorising about "history," for we need at this point only the notion of scholarly reading, and can safely recognise that historians, including historians of ideas, are usually well trained in that, whatever else is involved. Here are two possible outcomes of such imagined scholarship in the present context, offered as possible truths warranted by informed and scholarly reading of relevant texts and other interpretable remains: Morton White, a pragmatist, was interested in philosophical theorising about history. ${ }^{1}$ W. V. Quine, another pragmatist, was not. ${ }^{2}$ We need no more examples than just these two to make two simple points: the connection between pragmatists and being interested in philosophical theorising about history now seems "accidental" or "contingent," in the philosophical senses of those words: at least one pragmatist is, at least one pragmatist isn't, and the contrast is cast in terms of the pragmatists' individual psychologies (how "interested" they were in philosophical theorising about history). We seem to need further "historical" investigation into particular pragmatists to take the matter further.

However, we may suppose that we are philosophers rather than historians, although it remains to be seen how sound that separation is. An elementary distinction between philosophy and history is illustrated in the following: we may imagine historians to ask, for example, if some particular pragmatists were interested in philosophical theorising about history; we may suppose philosophers to ask instead if pragmatism is "intrinsically connected" to philosophical theorising about history. Philosophers and historians alike seek "truth," but perhaps of different things: historians seek truth about who believed what; philosophers seek truth about connections between ideas, where who had those ideas may be incidental. Philosophers thus sometimes address the "history of philosophy" - past philosophers - in what seems a peculiarly philosophical rather than a historical way. Here is Peter Strawson: "when I refer to the system of Leibniz, I shall not be much concerned if the views I discuss are not identical at all points with the views held by the historical philosopher of that name. I shall use the name 'Leibniz' to refer to a possible philosopher at least very similar to Leibniz in certain doctrinal respects; whether or not they are indiscernible in these respects matters little." ${ }^{3}$

Unusually explicit among philosophers about this matter, Strawson intended by this to block any complaints against his references to "Leibniz" that he imagined might be made by "proper" historians. He believed that the "proper" historians' sense of historical scholarship, as involving the grounding of historical assertions with appropriate historical evidence, material that they interpreted with accuracy and respect, ${ }^{4}$ was not relevant to what he was engaged in. Philosophical scholarship required instead exactness of expression and respect for logical reasoning. ${ }^{5}$ Philosophers like Strawson (and a number of pragmatists are like Strawson) saw themselves as engaging in a dialogue with "possible philosophers," with the analytically improved constructs of past philosophers; they thought about an imagined improved world where, unlike the actual historical world, the people were not, as they saw it, made of straw. Historians, by contrast, characteristically thought that one could not get much more straw-like than merely imaginary people.

5 We would need, I have suggested, further historical investigation into particular pragmatists to recover any interest of theirs in philosophical theorising about history. However, following Strawson, claiming that pragmatists have an interest in philosophical theorising about history clearly need not be a genuine description of some actual pragmatists' psychological dispositions. Moreover, despite Strawson's attitude to the history of philosophy, the claim need not even be the ascription of a rationally 
constructed attitude to (some) analytically improved relevant possible pragmatists. It may be, rather, a comment on the intrinsic (arguably, stipulated) nature of pragmatism "itself"; it would not at all be the outcome of miscalled "historical" research, imaginary or otherwise. On the contrary, setting the historical question as "did the pragmatists Morton White and W. V. Quine have an interest in philosophical theorising about history?" presupposes that White and Quine were "pragmatists," a judgement that (given the supposed contrast with historians) only philosophers could make, for it is not a judgement made on historical evidence (assuming that to require some highly constrained derivation from past texts) but is, rather, and relative to that, "a priori" in some way. ${ }^{6}$

6 Whether White and Quine were "pragmatists" requires an understanding of what philosophers think of as (a relevant part of) the history of philosophy. It is very usual for philosophers to think in a context of ideas set by what they see as the history of philosophy. But then, it is very usual for historians to address what seems to be exactly the same context of ideas, and they use the very same texts for the purpose as philosophers do. Philosophers and historians alike would seem to need to know what was meant by the texts in question, and, given similar skills in interpretation, this suggests we might find it difficult to distinguish the disciplines. ${ }^{7}$ However, we could try to force a distinction in the following way, by importing a certain theory of meaning: a philosopher, in order (for example) to assess the grounds of its truth or the validity of its deduction from others, might well ask what a particular sentence in the text means, and will often think of that as a matter that is determinable independently of any "context," which they might well deliberately ignore; the historian, by contrast, might well ask what the author of the text meant, and think that to be a matter that depends - even depends in its entirety - on the "actual context" of its being said. ${ }^{9}$

7 However, this is not a very useful way of making a distinction between history and philosophy. Many historians, whatever their interest in some form of "context," suppose that they do not need a "theory of meaning" to make sense of their evidence, for they often think, as some philosophers had thought pre-war, ${ }^{10}$ that what a person meant by uttering certain words was neither more nor less than the meaning of the words in that utterance. Historians often treat an utterance as having a transparent meaning independently of its context, much as a philosopher would commonly treat a statement of mathematics. It is usually philosophers rather than historians who are aware of a contextual approach to meaning (even if they rarely use it for statements of mathematics). ${ }^{11}$ For example, followers of the later Wittgenstein think of "meaning" as "rule-governed," so that a case for philosophy being indistinguishable from a social science is arguable, ${ }^{12}$ while other philosophers of language have developed "speech act theory." As explained by Strawson in referring to J. L. Austin: "Given that we know [...] the meaning of an utterance, there may still be a further question as to how what was said was meant by the speaker, or as to how the words spoken were used, or as to how the utterance was to be taken or ought to have been taken." 13

8 Yet we should note here Strawson's firm distinction between "the meaning of an utterance" and the other, "further," features of the "meaningful" situation. He did not take or allow the more radical step of holding that we do not know "the meaning of an utterance" unless we know how what was said was meant, or how the words spoken were used, or how the utterance was to be taken or ought to have been taken. What view do, or should (for, following Strawson, we may need to improve the expression of their 
positions), pragmatists take about this? While they may well have a larger vision than Strawson, it matters not, at this point. If "the meaning of an utterance" is available independently of "context" - whatever "context" is - it is available to philosophers and historians alike, who can share access to the ideas involved. Conversely, if "the meaning of an utterance" is not available independently of "context" then, again, philosophers and historians alike have access to meaning on whatever basis is involved.

It would be mere dogma on philosophers' part to insist that historians do or should deal only with the contingent psychological characteristics of past individuals (their "interests"), while philosophers alone are entitled to assess the (logical, epistemic or metaphysical) merits or "truth" of the substantive contents of the thoughts they had; historians regularly do that sort of thing despite any such insistence. After all, the actions historical individuals engaged in likely bore a close relation to the substantive contents of the thoughts they had, and how meritorious those thoughts were might well be of historical relevance requiring historians' judgement. While the history of pragmatism often displays serious practical engagement with the world in which pragmatists found themselves, it would be a mere contingency if some philosophers did not often act much on the basis of their own ideas, where the content, however better in quality than the usual run, did not generate in them sufficient confidence to warrant their acting, so that those philosophers became historically irrelevant. For my part, I think of myself as being pragmatic when I allow historians to invade my philosophical space, while - as will be seen - I equally think myself able to dip in and out of history as I choose. There is plainly some overlap between philosophy and history where "meaning" is concerned, and any interest in philosophical theorising about history may also be an interest in metaphilosophical theorising about philosophical inquiry. But that bathetic conclusion says nothing that relates especially to or involves a commitment to pragmatism, although some pragmatists may well form a view about it.

Here I will highlight a point I will make use of later: in so far as "meanings" are not to be understood as fixed eternal quasi-mathematical objects appropriate for more abstract theorising then we should note some degree of temporal extension to the "meaningful" features of the situation to match the temporal extension of the local "context" involved. This may well seem to open the door to a full historicising approach, but in fact most analytical philosophers shunned what they saw as a risk of relativism and chose not to take that route. Analytical philosophers did not notice or think relevant any temporal duration of speech acts, usually continuing to suppose that the sentences uttered in such a meaningful context had some fixed meaning, while where the context allowed a "thicker" meaning - such as in Austin's "performative utterances" 14 - they were thought to be atemporally analysable in such terms as an utterer's "intention" or a hearer's "uptake," notions which were themselves atemporally analysable. It was difficult to find analytical philosophers or even concerned historians moving beyond the temporally immediate where "meaning" was concerned. Theorising about meaning took place from what I have called elsewhere a "philosophical stance," ${ }^{15}$ as if the theorising were dealing with quasi-mathematical objects.

11 Nevertheless, whichever discipline has the skills most appropriate for answering it, a question remains open to us: is there an "intrinsic" connection between pragmatism and philosophical theorising about history? Here, in so far as that is possible, we direct our attention to the ideas referred to in the question. If we have also to attend to the persons alleged to have held those ideas, or to the "contexts" in which the ideas were thought or 
expressed, so be it. One way or another, we can examine - analyse - these ideas, it seems. One point is readily apparent: if there is some intrinsic connection between pragmatism and philosophical theorising about history then there seem to be at least three forms it could take: pragmatism requires attention to philosophical theorising about history; attention to philosophical theorising about history requires us to adopt pragmatism; both of these. Given the multifarious versions of "pragmatism," not least the existence of Quine's philosophy, it would be unnecessarily heroic to assert the first form of "intrinsic connection" here, and since the third form includes the first, a similar objection can be made to that. Rather, in the present essay it will be shown historically (indeed, autobiographically) how philosophical theorising about history required in practice the adoption of a particular version of pragmatism.

As already remarked, it is very usual for philosophers to think in a context of ideas set by what they see as the history of philosophy, and we propose to enter here this world of ideas. We need not, however, limit ourselves to the world of "philosophical" ideas, for our concerns with "meaning" affect the world of ideas imagined on the basis of education or memory or of empirical evidence or historical remains or "reason" more generally: our "history" in a more full-blooded sense, ${ }^{16}$ indeed, we are likely to imagine here not just the past but also the present and we often think of history as continuing into the future. Now it may be that we believe, following Strawson for example, that philosophical analysis enables us to abstract from this overarching context the ideas that we propose to address and analyse, that is, we can attend to particular sentences in texts and take their meanings as fixed and sufficiently transparent to us so that they are identifiable and reidentifiable in whatever other small contexts we find them or use them as our own. It may well be that (some) pragmatists would not allow such "abstraction." Nevertheless, however we attend to the ideas at issue and however "free-standing" it is appropriate to think them, in practice we pick them out from a welter of other ideas we might attend to instead. This world of ideas - this ongoing history - is imagined to be temporally extended. Philosophy about "history" in this sense is not necessarily philosophy about "history" conceived as an epistemic discipline. We conceive our situation here as involving an object of thought - the context of a welter of thoughts (possibly inseparable from each other) constituting ongoing history including the history of philosophy - that has a duration well beyond the immediate, and both philosophers and historians can feel at home in it. My "pragmatism" here is therefore tolerant. ${ }^{17}$ As philosophers, as historians of philosophy, or as historians, the temporally extended object that one is thinking about here is essentially mentally "observable" as fixed, enduring, continuing, changing or becoming, perhaps with temporally distinct and moveable parts, perhaps not, perhaps with an internal structure, perhaps not, perhaps evolving, perhaps not. There would have been no evolution for Plato's Forms.

We thus adopt here what I have called elsewhere a "historical stance," 18 which characteristically has as its object of thought something which is imagined to spread over an indeterminately longish period of imagined time. However, one does not have to be any kind of theorist or historian to adopt it, for it is a stance appropriate to the experienced temporal continuity of our everyday lives. An apparent disadvantage of this point is that, precisely in so far as the world of history is continuous with the everyday, an adequate philosophy of the "everyday" - maybe some form of pragmatism - might be an adequate philosophy of history too, and attention to the philosophical issues particularly concerned with "history," in particular with "history" conceived as the 
discipline of historiography, might well be able to be bypassed. In any event, this ongoing "historical" world is one of the imagination or consciousness. Despite the Cartesian thought that imagination and consciousness are private to the individual, here they are not private but essential features of our shared world, just as meaningful language itself is. It is not, of course, imaginary; ${ }^{19}$ it is real time that is imagined. Those like Strawson theoretically inclined to traditional philosophical analysis may well imagine a temporally extended, yet temporally immediate because also eternal, quasi-mathematical shared world of reidentifiable meanings that are, following Frege, ${ }^{20}$ fixed (or at least comparatively determinate in any flexibility they are supposed to have), whereas those inclined to the "historical" may imagine a shared world that is temporally extended and structured in terms of concepts that can cover change and can themselves change, even, with Bakhtin, change in some extreme way. ${ }^{21}$ On the other hand many historians share a commonsense, if not naïve, view that "meanings" can be taken for granted as broadly unchanging, whereas it is the philosophical speculators who see revolutionary possibilities here. ${ }^{22}$

\section{From History to Hate: Redescribed Recollections}

Given this world of ideas we propose to enter, where should we begin? "In treating of [...] ideas, whatever order we adopt has its own disadvantage," wrote F. H. Bradley. ${ }^{23}$ This is because "there is not and there can not be any such thing as a mere idea, [...] standing or floating by itself." "Really, here as elsewhere, what in every sense comes first is the concrete whole, and no mere aspect, abstracted from that whole, can in the end exist by itself." ${ }^{24}$ As Louis 0 . Mink put it, "despite the fact that an historian may 'summarize' conclusions in his final chapter, it seems clear that these are seldom or never detachable conclusions." ${ }^{25}$ It is a "ruinous superstition," Bradley concluded. ${ }^{26}$ With these and similar arguments Bradley justifies his view at the beginning of his The Principles of Logic, first published in 1883, that "It is impossible [...] to know at what point our study should begin." ${ }^{27}$ Yet Bradley is pragmatic at least in this sense: he is going to try: "[...] If we incur the reproach of starting in the middle, we may at least hope to touch the centre of the subject. ${ }^{28} \mathrm{He}$ would see if it worked. ${ }^{29}$

With the help of my imagination informed by memory - or maybe it is the other way around $^{30}$ - I will now enter this temporally extended world of ideas around 1970, when I embarked on postgraduate research into the analytical philosophy of history. ${ }^{31}$ For me, in this bit of personal academic history, the problems involved in philosophical theorising about history came before I gave any attention to pragmatism. But I was not at all sure whether the problems were epistemic, or metaphysical, or logical, or even political, and I was not at all sure whether the problems had to do with history as a "discipline" as opposed to "history" in one of its many other senses. Indeed, I had no idea at all what the problems ought to be conceived to be. Beginning in wonder and doubt, like many intending philosophers I was tempted by the desire to start addressing from scratch those matters about which one may be curious or astonished. ${ }^{32}$ But where was "scratch"?

It lies not so much in either wonder or doubt themselves, or even in the things wondered about or doubted, but rather in the recognition that these worries - indeed, puzzlements and disagreements of many kinds - need to be dissolved, resolved or overcome. That is a pragmatic thought. It lies in the recognition that such matters be investigated as necessary and appropriate, inevitably with assumptions made about the form of the 
investigation and about where any burden of proof lies, assumptions that are themselves likely to generate controversy. Descartes thought that "scratch" in such recognition was "here" and "now," and interpreted those as referring to his immediate and personal consciousness and such unavoidable and undeniable thoughts as he found it to contain, with philosophically "rationalist" criteria for the latter, generating the view that the dissolution of doubt and the overcoming of puzzlements involved particular perennial issues that required universal and permanent solutions, reflecting the eternity that God, mathematics and for that matter Plato's Forms, occupied, and defining also the nature and limits of the philosophical. There seemed nothing in Descartes' consciousness that was temporally extended in a historical sense, or indeed in any sense other than the "eternal," and nothing that was shared with others. Problems generated by the "here" and "now" in a more mundane sense - temporally localised compared to eternity, no doubt temporary and changeable - were beneath the ken of those reflecting on the eternal, so that, for example, "history, expelled from the body of knowledge proper by Descartes in part I of the Discourse, is still regarded with suspicion by his successors today. ${ }^{{ }_{33}}$ Hume, long thought of as primarily a historian, ${ }^{34}$ started his philosophy in much the same place as Descartes but with "empiricist" criteria, interpretable as assuming that it was the "here" and "now" of individual phenomenal experience that marked "scratch," and to some extent he shared with Descartes an understanding of the limits of the philosophical. Commonly evaluated as if it offered a new and different range of solutions to Descartes' supposedly perennial philosophical questions, Hume's philosophy was in the light of Descartes' work usually ascribed a sceptical character, but his history "is recognizably within a classical tradition of dealing with public affairs and public men." ${ }^{35}$ Usually thought of as distinct in some principled way, how Hume's philosophy and history are connected is an intriguing question, ${ }^{36}$ although that will not be dealt with here.

Perhaps supreme among philosophers, Kant sought a rapprochement between rationalism and empiricism, but like many historical philosophers before and after him the issues he addressed were set by his forebears. ${ }^{37}$ His "here" and "now" included those inherited issues. He set still more puzzles for his successors, particularly when he attempted to apply pure reason to the course of history, ${ }^{38}$ and my "here" and "now," when I began to research in philosophy, included many of those puzzles. None of these philosophers helped me much at the time, not least because "scratch" in post-Wittgenstein 1970 was widely accepted by philosophers as meaningful language in a shared world. Understanding this need not involve Wittgenstein's "rules," but a science of human behaviour seemed highly relevant and most of us were "pragmatists" in at least one sense: said Charles Sanders Peirce, "It is not 'my' experience but 'our' experience that has to be thought of"; as Bryce Gallie summarised this, "language is essentially a vehicle whereby one expresses those parts of one's experience that are general, that must be 'ours' rather than 'mine' if they are to be communicated at all." 39

I came to research in this area with a fairly sound grounding in the history of philosophy and with a background of study in philosophy of history. ${ }^{40}$ At that time the philosophy of history was distinguished into two areas. In the usage of W. H. Walsh, these were "speculative" and "critical" philosophies of history. ${ }^{41}$ In the usage of Arthur Danto, these were "substantive" and "analytical" philosophies of history. ${ }^{42}$ "Speculative" or "substantive" philosophy of history had had a comparatively benign past prior to the twentieth century. The "meaning" of history has been a perennial worry for humanity, 
expressing as that issue can a concern about our past, present and future, with religion often understood to give the historical "meaning" sought, characteristically telling us "why we are here" or "what we are for." ${ }^{43}$ During and since the Enlightenment, and beginning with Biblical exegesis using skills first learnt in studies of classical texts, historical understanding had been developed in ways distinct from religion, with the "meaning" of history conceived as a subject for rational and secular attention rather than being a matter for religious authority. We may summarise Vico from 1725: "Because, as a species, we have 'made' history and the social world, we - humanity or its representatives - have the capacity to transform both." ${ }^{44}$ That we can only know what we make - verum factum - is an even briefer summary of his epistemological position. That thought offers an opportunity for a pragmatic approach.

However, by the Second World War it came to be held that "speculative" or "substantive" philosophy of history, thought of as a historicist precursor of various forms of totalitarianism undertaken in the name of "progress," was a misconceived if not evil activity that had been well demolished, in then current theory at least, by Karl Popper, ${ }^{45}$ and - thanks also to the publicly defended pluralism of Isaiah Berlin - it was thoroughly out of tune with the time. Patrick Gardiner had been able to write an introductory book in the area without referring to speculative philosophy of history at $a l l ;{ }^{46}$ Walsh, who had published his Introduction one year earlier than Gardiner, had felt it necessary to apologise in case it was thought to be speculative. ${ }^{47} \mathrm{I}$ was familiar with the thought of Collingwood, ${ }^{48}$ Bradley, ${ }^{49}$ and various works by historians, which were most commonly (it then seemed to me) the result of philosophically untutored reflections in their dotage, although Herbert Butterfield's The Whig Interpretation of History was a distinguished exception to that judgement, ${ }^{50}$ while I had some of the most advanced philosophical discussions with the historian Maurice Cowling.

21 Inevitably, one was allowably engaged only in "critical" or "analytical" philosophy of history. While philosophy of science at this period engaged with big epistemological, logical and metaphysical issues, these were not open to philosophers of history. Analytical reflection about big philosophical issues did not require attention to what historians got up to or to what they thought. ${ }^{51}$ The nature of historical "facts" seemed problematic, but nobody supposed that one needed any more than current philosophy of science to address the epistemic difficulties involved here, ${ }^{52}$ while there would be no need for a pragmatist approach in philosophy of science unless one were already committed to it. Five works particularly set the scene for me in 1970: Carl Hempel's "The function of general laws in history," ${ }^{33}$ William Dray's Laws and Explanation in History, ${ }^{54}$ Bryce Gallie's Philosophy and the Historical Understanding, ${ }^{55}$ Arthur Danto's Analytical Philosophy of History, ${ }^{56}$ and Morton White's Foundations of Historical Knowledge. ${ }^{57}$

All these were concerned with the nature of historical explanation, and allowable philosophy of history seemed to consist of nothing else. Hempel imposed his empiricist philosophy of science on historical writing using a Humean model of causal explanation, while the historian Dray objected to this by arguing for the role of reasons in historical explanation. Causes versus reasons in the explanation of human action was an ancient debate that continues today, but - almost to prove what a backwater philosophy of history had become once it had lost its evil speculative edge - as this debate became once again more philosophically valuable it morphed into the philosophy of action ${ }^{58}$ and left behind philosophers of history. It was not as if historians explained human actions particularly well, and the place for debate, if anywhere outside core philosophy, would 
have been in psychology or the philosophy of the social sciences or, as earlier noted, the philosophy of the "everyday."

Gallie, Danto and White, by contrast, highlighted "narrative," which seemed to be a kind of explanation quite different from what the scientists produced. One knew a "narrative" when one saw it: historians produced them at a great rate and each of them had lots of sentences in it. Gallie saw such stories as "followable" and harked back to the romantic philosophies of around 1800. These were difficult to grip in terms of analytical philosophy, and left one with an uncomfortable feeling that there had to be more to narratives than a large collection of facts organised in an entirely aesthetic way; even Danto's valuable and arguably pragmatic "rules of redescription" covering what he called "narrative sentences" seemed in the last resort to be aesthetically driven. ${ }^{59}$ Aesthetics, it was commonly assumed at the time, could not possibly have any epistemic role. ${ }^{60}$

Danto and White, in subtly different and clever ways, tried to make analytical sense of narratives mainly by offering - indeed forcing on them - a version of Hempel's so-called covering-law theory of causal explanation as modelling the constitutive links that supposedly tied together the explanatory elements of narratives. That just seemed to me to be an unnatural fit (were there "constitutive links" that needed to be modelled?), but then there was no other theory of explanation available (and should it be a theory of explanation that I required?). Putting these concerns aside for a while, I threw myself instead into the fast developing work at Cambridge in the History and Philosophy of Science Unit, where, apart from exciting developments in empiricist philosophy of science, like many other research students I studied in depth and tried to make sense of the works of Kuhn, Quine and Feyerabend, ${ }^{61}$ while cracks appeared in the received understanding of empiricist philosophy of science. ${ }^{62}$ But while my understanding of history and philosophy of science became better informed and more sophisticated, I was still unable to unpack the dimly perceived philosophical confusions that making sense of "history" seemed to require.

Historians took their positions seriously, more seriously than current philosophical understanding of their discipline made plausible. While they often agreed on "facts," their invective against each other was educational and entertaining beyond the ordinary, and the deep-rooted differences between them clearly went far beyond mere matters of aesthetic or even political choice. "It's hate," I heard at a recent colloquium of historians. ${ }^{63}$ Philosophers might differ on fundamental as well as stylistic issues too, but, even though there was among them the occasional threat ${ }^{64}$ and ad hominem bullying in seminars was not uncommon, by contrast historians in general left the philosophers far behind in depth of feeling and mastery of vicious language. On what is for me now a memorable afternoon I went to the Library of Peterhouse (then in an attic and not the grand affair it is now) to search out, if I could, two historical accounts of much the same thing that were in such clear opposition to each other that I might be able to identify the philosophical issues I only dimly saw. Indeed, I later came to realise that it was opposition that was the issue and that it was staring me in the face.

\section{Joyce and a Synchronic View of Quine}

26 I knew that A.J.P. Taylor had annoyed a lot of fellow historians, so I started with his English History 1914-1945. ${ }^{65}$ Noteworthy was his account of William Joyce, otherwise known as "Lord Haw-Haw." Joyce had been charged with high treason on the 17th September 
1945, it being alleged that "he being a person owing allegiance to the King, did traitorously adhere to the King's enemies in Germany by broadcasting propaganda." ${ }^{66} \mathrm{He}$ was found guilty, this was upheld on appeal, and he was executed at Wandsworth Prison on 3rd January 1946. Taylor dealt with this matter in a little detail, ${ }^{67}$ observing "Technically, Joyce was hanged for making a false statement when applying for a passport, the usual penalty for which is a small fine." ${ }^{68}$ I could see well enough that a remark like this could not plausibly be a contribution to historical knowledge, and was best ignored (after all, "technically" he was hanged for what he was charged with); on the other hand there was much apparently truthful information in Taylor's account that seemed - before one saw any contrasting account - both to express and to warrant his pro- rather than anti-Joyce view.

27 After puzzling over the Library shelves for a while I found a suitable anti-Joyce foil to Taylor in Chambers' Encyclopaedia: “William Joyce, 1906-46, traitor [...]" Taylor and Chambers gave me the brief narrative accounts, for and against Joyce, that I required. However, each needed considerable revision to remove tendentious, morally judgemental or "ideological" sentences, false implications and implicatures, and other features similarly epistemically problematic, and this left me with a number of sentences that were, on the face of it, true, or - if one is unhappy with "truth" - at least well warranted in normal historiographical terms. An important consideration in my next move was this: against F. H. Bradley's view that "there is not and there can not be any such thing as a mere idea, [...] standing or floating by itself," ${ }^{69}$ I knew that analytical philosophy permitted me to ignore any original context of other sentences ${ }^{70}$ and allowed me to take each sentence as a free-standing whole, move it about and juxtapose it with other sentences as I thought fit, subject only to avoiding any inconsistency in the outcome. So far as current analytical logic and epistemology were concerned each sentence, wherever it was placed, would carry with it undisturbed whatever truth-value it had, or whatever epistemological warrant it had. Given this assumption, I formulated the following pair of accounts, selecting from Taylor and Chambers:

(A) "Joyce was born in Ireland, according to the application for a British passport made by him in 1933. He became a Fascist, for whom Sir Oswald Mosley, the 'Bleeder,' was too moderate. In August 1939, a few days before the outbreak of hostilities, he went to Germany and offered his services to the German ministry of propaganda. He was the Germans' principal English broadcaster (known as 'Lord Haw-Haw' from his manner of speaking). He was executed as a traitor."

(B) "Joyce was born in New York. His father was a naturalized American citizen. Joyce never made a formal request for British nationality, though he spent most of his life in England and was regarded as patriotic. In September 1940 he became a naturalized German. Joyce attracted to himself the mythical repute of Lord HawHaw. These legends were the manufacture of war-nerves. He was executed as a traitor."71

These are brief, but that is sufficient for the argument. It is not apparent from the superficial text alone whether these short accounts are fictional or historiographical, but that is not here relevant. What does matter is that they are offered as factually true: an exact analysis shows that every sentence in each of the two accounts is indeed individually true, or (for those who prefer it) at least accepted by historians as warranted by the historical evidence. They were sourced in an appropriately historical way. One issue is what historians characteristically mean when they think of an account being true. There is no doubt that a part of this is that the individual sentences of the account should each severally be thought of as true, but that is not enough. Removing tendentiously 
expressed sentences and the like had not avoided the obvious feature that there remained highly tendentious selection - why, for example, leave out of the (B) account of Joyce reference to his having been the Germans' principal English broadcaster, and include only a reference to the mythical stories about Lord Haw-Haw (and there were some)? - but it was precisely this need for the selection to be itself truthful that I had to address.

It seemed clear to me that objective "selection" required rational grounds for determining the relevance of sentences, and that holding it to be merely an aesthetic choice was utterly implausible. The problem was surely in some way epistemic. "Explanation," by contrast, seemed for a moment to offer an answer: it is plain that the (A) account does, and the (B) account does not, explain in a followable way why Joyce was executed as a traitor. But "explanation" is an unsupportable criterion of truth, knowledge or cognate matters. Sir Walter Scott saw it clearly: "were we to point out the most marked distinction between a real and a fictitious narrative, we would say that the former, in reference to the remote causes of the events it relates, is obscure, doubtful, and mysterious; whereas, in the latter case, it is a part of the author's duty to [...] account for everything." " ${ }^{2}$ Explanatory clarity is no guide to truth; for Scott it was a sign of fiction. Intriguing for a moment was the thought that a logical argument ${ }^{73}$ is also a selection of sentences, and here a "truthful" selection might be cashed in terms of validity. Perhaps there was a rational analogue for validity where historical accounts were concerned? Yet it is elementary logic to distinguish validity from truth, and the validity of an argument says nothing whatever about the truth of its constituent statements. This suggestion seemed to me to be one among many dead ends. ${ }^{74}$

I later found that Ernest Nagel had said that "it is not inconceivable that each of two historical accounts of the same period could contain only indisputably correct statements about matters of particular (or 'simple') fact but that each would nevertheless be marked by a distinctive bias." However, he continued, "the argument hardly warrants a wholesale skepticism toward the possibility of historical objectivity." ${ }^{75}$ But I had no doubt that my examples proved that that is exactly what it did. What made the matter epistemic in some centrally important sense was that the (A) and (B) accounts were incompatible, inconsistent with each other in some historiographical way. No historian, indeed, no ordinary reader, could accept them both as true. At least one of them - quite probably both of them - had to be false, and one was not going to find that falsehood in one of the constituent sentences. Despite every sentence in each account being consistent with every other sentence in both accounts, the selections of sentences presented as they were involved two meaningful but incompatible or inconsistent "wholes."

31 While each sentence had a "truth-value" and an epistemological warrant that did not vary with the context of other sentences, just as current analytical logic and epistemology permitted (indeed, was committed to), nevertheless there was a sense of "whole account truth" that then current analytical logic and epistemology did not and, I later came to see, could not recognise. Yet the situation was in one sense "logical," for there seemed no reason why one could not use the elementary tools of propositional logic in dealing with the unit of meaning that a "whole account" expressed. On the other hand, I came to see later that one could not use the tools or the assumptions of predicate logic. I argued for the need for a philosophy enabling us to reason with respect to "relevance," understanding that as being a quality of a sentence that changed according to the historical account - the context of surrounding sentences, at least - that contained it. 
"Statements do not carry a 'relevance-value' with them just as they carry a truth-value, regardless of where they appear." 76 "Whole-account-truth" was clearly historical truth in an important way but it was not truth-functional relative to its constituent sentences. One could not usefully treat a historical account as a conjunction. This, then, was the epistemically problematic dimension of historiography. Received empiricist philosophy of science offered no help, I argued in $1974 .{ }^{77}$ I then spent a while trying to make sense of sets of sentences in terms of set theory, but that too I came to think a dead end.

In due course I was tempted, not particularly to use "pragmatism" as a general resource for this problem, but at least to use Quine's conception of what later was called the "web of belief." In contrast with Hume's position, on Quine's approach in "Two dogmas" we hold that our beliefs look for their warrant, not to particular experiences, but to experience "as a whole." The web initially looked to me like sets of sentences, just as a historical account did, and it seemed as if that conception might be fruitful. Following the "impossible term-by-term empiricism of Locke and Hume," Quine had famously said that "what I am now urging is that even in taking the statement as unit we have drawn our grid too finely. The unit of empirical significance is the whole of science." 78 That was a powerful - indeed blinding - thought. Later I reflected, as it seemed to me that Quine quite plainly had not (at least, not in a serious way), that it was a pragmatic question how large a "unit of empirical significance" was to be taken to be, and that we could hence treat narratives as a central unit for the purposes of the epistemology of historiography. Quine clearly had no recognition that the notion might be used in this way. ${ }^{79}$ While Quine's pragmatist philosophy may not look historicist and was plainly not intended to be, successors of his such as Richard Rorty drew out some historicist implications of pragmatism, although not especially with any epistemic issues relating to historical accounts in mind; ;0 after all, the "everyday" was sufficient.

For Quine in "Two dogmas," experience alone warrants no particular beliefs as certain. We are to recognise that no one of our beliefs is so fully and directly related solely to experience that we are forced to keep or amend just that one if experience requires it. Equally, what we choose to treat as a priori is not a matter independently given to us by the demands of pure reason or anything of the kind, for reason does not itself generate substantive beliefs. Quine recognises that, in trying to make sense of the experienced world, there is room for conscious and deliberate decision regarding which sentences we propose to hold true and which we propose to discard as false. It is open to us to amend our knowledge claims as we find pragmatically convenient, and there are in principle many ways of effecting any required change. As Isaiah Berlin put it, "Any one proposition or set of propositions can be shaken in terms of those that remain fixed; and then these latter in their turn; but not all simultaneously." ${ }^{81}$ As Quine put it, "Any statement can be held true come what may, if we make drastic enough adjustments elsewhere in the system." ${ }^{82}$ Again, "no statement is immune to revision," ${ }^{83}$ so it is not merely that "there is much latitude of choice," ${ }^{84}$ but that unlimited adjustment to the web of beliefs is in principle available..$^{85}$

If Quine is right here then it is not the "statement" or the Lockean or Humean "term" or a particular "belief" that is the unit of empirical significance but rather some meaningful "whole," whether "the whole of science" or, as I saw it, just that "whole" consisting of a particular historical narrative understood as a set of sentences. I felt I could take from Quine at this point his explicit holistic view that particular beliefs are constrained by their relationship to other beliefs within our total set of beliefs. We can then describe the 
set of beliefs, sentences or statements as he does, as a "web" of beliefs, with such implications of constraint and stickiness as the word "web" suggests. The web of other beliefs are the sole constraints upon a particular belief, and are equally the only source of validation or justification for that belief. For the sets of sentences in historiographical accounts, the "beliefs" I argued to include such sentences as express the evidence or the "historical sources" for them. These characteristically appear in footnotes to the account, so that the selection of sentences involved in producing a historical account are more than appear in the explicit narrative in the main text but includes also roots in the much larger world of historical "ideas," sources themselves very often also of narrative form.

Yet what makes this "whole of science," or "whole historical account," true, rather than merely being a free-floating and false construction? Quine himself did not take to heart his own assertions in "Two dogmas," for, against his view that the term and the individual statement were not "units of empirical significance," we find him in Word and object ${ }^{86}$ introducing the notion of "stimulus synonymy" which looks like nothing so much as a route to permitting the causal stimulation of belief, hinting that reality is independent of our conceptualisation and comes in "units of empirical significance" that are in belief-sized bits. Now it may well be, once we have allowed that it is a pragmatic matter what the "unit of empirical significance" is, that the whole of science, a historical account and an individual sentence can each be "units of empirical significance" for different purposes, and even a fragmented view of our minds, our shared consciousness, may become appropriate. But this makes it implausible to suppose that one or other of these units is epistemically fundamental relative to the others. That analytical philosophy generally, and even Quine himself, currently assumed that some version of "atomic sentences" was indeed fundamental was an unfortunate context for trying to make sense of what was going on in the expression of historical knowledge.

Apart from what seemed to me to be an incoherence in Quine's position at this point, the difficulty for the epistemology of history was that "grounding" selections of sentences in such terms took one back to the old, and failed, view that historiographical truth involved a unified synthesis of independently available atomic facts. First get your facts, then select them "properly." But no ground for synthesis seemed available, while Quine's view that the web involved some constraint on a particular belief because "Any statement can be held true come what may," ${ }^{87}$ if we make drastic enough adjustments elsewhere in the system " offered no more constraint than "consistency" between sentences or beliefs. This might (although it probably didn't) work for short sentences and the like, which pragmatically we could allow in certain contexts or for certain purposes to be our "units of empirical significance," but the requirement of such consistency was already met in the (A) and (B) accounts, and it was consistency between statements that Quine clearly (although inconsistently) had in mind here, rather than consistency between "units of empirical significance," as - pragmatically - we could take historical accounts to be.

Berlin's expression of a similar position in terms of "propositions" involved a similar failure. Consistency between accounts was not only different from consistency between their constituent propositions or statements, it did not even require it, for statement-truth, while clearly desirable, I had shown to be not even a necessary condition for wholeaccount-truth. ${ }^{88}$ The old idealist idea of "degrees of truth" seemed tempting, although I did not follow through with that thought. Irrelevant falsehoods, like irrelevant truths, had no relevant cognitive content, while even a false statement (most obviously where the error was trivial) could be relevant and be an essential feature of the whole true 
account. This failure of a particular kind of compositionality occurred in both directions. Just as one cannot assure oneself of whole-account-truth on the basis of constituent statement truth, so one could not assure oneself of constituent statement truth on the basis of whole-account-truth. Bradley was right when he said "what in every sense comes first is the concrete whole, and no mere aspect, abstracted from that whole, can in the end exist by itself," " ${ }^{99}$ although he had slightly overstated the point, for while analysing or breaking up the "whole" provided no assurance or warrant whatever of constituent statement truth and might well result in falsehood, it was not a necessary outcome, for the conclusion was not a matter of principle but of practice. One might be accidentally lucky to extract some true sentence, but even then one had no assurance of its relevance, the crucial epistemic ground for the expression of historical knowledge.

\section{A Diachronic View of Quine}

There was a further important point: I came to realise that in worrying about how the web was to be understood and structured I was myself adopting a synchronic view of it, much it seemed as Quine and everyone else did, and that I was thereby adopting what I called earlier here a "philosophical stance." It was necessary to take much more seriously the idea that the web should be understood as temporally extended: Quine's "web of belief" should be conceived in diachronic and historiographical terms as a rolling web. Just as Quine had said, "To learn 'apple' it is not sufficient to learn how much of what goes on counts as apple; we must learn how much counts as an apple, and how much as another," ${ }^{90}$ we needed to think of the rolling web as a web of reality-sorting expressions, ${ }^{91}$ where "expressions" referred not necessarily to terms or sentences or beliefs but, for historical meaning and truth, to narrative length units of meaning that counted or sorted shared experience in various ways. ${ }^{92}$ Matters such as representation or reference had subordinate status and were to be analysed in such terms.

We can now adopt a historical view of the rolling web in a more substantive sense. Think of this shared world of reality-sorting expressions in what we may imagine to be the early stages of its development, that is, the early stages of the development of language itself. We do not have to adopt the philosophically parochial supposition that in its early stages the development of language involved the creation of simple referring and descriptive atomic terms, enabling us to operate with "moderate-sized specimens of dry goods," in J. L. Austin's words, ${ }^{93}$ as if we had already analysed the world in which we lived. No doubt, with such an imagined language, we might develop a fairly successful practice of living a small life within closely bounded horizons, where "meaningfulness" need do little more than support our everyday engagement with other people, that is, support a way of life that is to a large extent a consequence of the few senses and small memory-sizes with which we human beings have been, to the best of our philosophical and scientific understanding, accidentally endowed.

Given this experientially brief and narrow life that we may imagine we once led, then it is no surprise that meaningful contributions to knowledge and understanding may be halfplausibly interpretable as having, as Aristotle claimed, a brief and narrow subjectpredicate form. Perhaps sadly (although there have been many theoretical developments and successes), philosophical assumptions since then have often been fashioned as imitating or mirroring Aristotle's substance/attribute metaphysics, with much work over the centuries that has attempted to explain "logic," "truth," "reference," "knowledge" 
and cognate concepts in terms of these ancient assumptions, and such assumptions continue to inform the post-Gottlob Frege predicate logic that many exact philosophers use today. Pragmatically, it surely has its uses; but answering the epistemic problems of history is not among them. The world, as shown by historians, scientists and mathematicians, is much bigger than that, and requires a more expansive sense of "meaningfulness" which is plausibly not translatable into such limited and ancient terms; the "academic person" has a "discourse many times larger, and he looks before and after many times as far." ${ }^{94}$

41 In the light of ancient and anthropological discoveries I will offer, not necessarily a probable, but a possible alternative. Early communication between people, and storage of what some of us call "information," seems to have taken place in terms of oral traditions which primarily took the form of stories or narratives. We might well think that these are refinements of still earlier linguistic attempts to express what is going on which involve concepts that we may now think of as "temporally extended" in two ways. First, the expression is itself "temporally extended" (for it takes time to present or to follow a narrative), while even the briefest of expressions takes some time to get across, given what may well be uncertainty over the receptiveness or uptake of the audience. Second, what the expression is "about" may well also be "temporally extended," for, comparatively unanalysed as experience then is, it might refer for example to "approaching flood" or "imminent storm," where a proto-version of what some philosophers of history have called a "colligatory concept" is adopted, ${ }^{95}$ but here we do not interpret such concepts as built up from simpler "facts" but rather as epistemologically prior to simple "facts" and involving a similarly large yet vague ontological construction and commitment. We may imagine early peoples, developing language as a tool, trying out such "concepts" to see how useful, how workable, how predictive, how memorable, these large expressions were for their experience of their narrow worlds, later refining them for more exact use where that was pragmatically possible. We continued to search for "meaning" in our lives in the larger senses of that, adopting religious answers early on, but eventually coming to use, for historical understanding, comparatively vast concepts such as "Renaissance" or "Enlightenment." Such summary terms were adopted not by historians alone but also to characterise their own situations by, in these examples, Vasari ${ }^{96}$ and Kant ${ }^{97}$ respectively.

As I remarked earlier, for me the epistemic problems of history came before Quine's version of pragmatism, and attention to the epistemic dimension of historical inquiry required me to develop from him the form of pragmatism I have described. I drew on his pragmatism to help solve the problems I found, and at no point found a more plausible source. But, being pragmatic, I allow that one day I might find one. My approach has inherently involved adopting a historical stance and Quine's pragmatism framed and facilitated this despite the unashamed philosophical stance that in the main he adopted. Just as he did not touch ethics, so he did not touch history, and in so far as he was a pragmatist - and the choice of descriptions and redescriptions that is inherent in the web (among many other features) suggests to me that there is no doubt that he was - it is implausible to suggest that there is any intrinsic connection between his pragmatism and philosophical theorising about history in any of the senses of "history." There may well, however, be an intrinsic connection between pragmatism more generally and what I have called elsewhere a "temporal stance," temporally extended object of thought characteristically much shorter than the object of 
a "historical stance," allowing us as pragmatists to hold importantly fundamental timeextended habits of human behaviour. However, this relates to the "everyday," to "commonsense," and a philosophical understanding of it would not seem to require attention to the philosophical problems of the discipline of historiography. By contrast, Morton White was a brilliant polymath of a scholarly pragmatic philosopher yet, despite his detailed essays into history and historical theory, his attention to the theory of history I found completely unhelpful. It was one of those ladders that one had to kick away after one had climbed it, itself a good pragmatic move. But that is hindsight.

\section{BIBLIOGRAPHY}

AUSTIN J. L., (1962), Sense and Sensibilia, London, Oxford University Press.

AUSTIN J. L., (1971), “Performative-Constative," in Searle J. R. (ed.), The Philosophy of Language, London, Oxford University Press.

BAKHTIN M. M., (1981), The Dialogic Imagination: Four Essays, Holquist M. (ed.), Emerson C. \& Holquist M. (trans.), Austin, University of Texas Press.

BERLIN Isaiah, (1980), “The Concept of Scientific History," in Id., Concepts and Categories: Philosophical Essays, Oxford, Oxford University Press.

BRADLEY F. H., (1874), The Presuppositions of Critical History, Oxford, James Parker.

BRADLEY F. H., (1922), The Principles of Logic, vols I and II, London, Oxford University Press, 2nd edition.

BURROW John, (2007), A History of Histories, London, Allen Lane.

BUTTERFIELD Herbert, (1931), The Whig Interpretation of History, London, Bell and Sons.

Coluingwood R. G., (1946), The Idea of History, Oxford, Clarendon Press.

CORNFORD F. M., (1908), Microcosmographia Academica, Cambridge, Bowes and Bowes.

DANTO Arthur, (1965), Analytical Philosophy of History, London, Cambridge University Press.

DAVIDSON Donald, (1968 [1963]), “Actions, Reasons and Causes,” in White A. R. (ed.), The Philosophy of Action, London, Oxford University Press.

DRAY W. H., (1957), Laws and Explanation in History, Oxford, Clarendon Press.

EDMONDS David, \& John EIDINOW, (2001), Wittgenstein's Poker, New York, Harper Collins.

EWING A. C., (1935), “Two Kinds of Analysis," Analysis 2, 60-4.

FEYERABEND Paul K., (1968 [1963]), "How to be a Good Empiricist - a Plea for Tolerance in Matters Epistemological," in Nidditch P. H. (ed.), The Philosophy of Science, London, Oxford University Press.

FEYERABEND Paul K., (1975), Against Method: Outline of an Anarchistic Theory of Knowledge, London, New Left Books. 
GALLIE W. B., (1964), Philosophy and the Historical Understanding, London, Chatto \& Windus.

GALLIE W. B., (1966 [1952]), Peirce and Pragmatism, New York, Dover.

GARDINER Patrick, (1952), The Nature of Historical Explanation, Oxford, Clarendon Press.

GEACH P., \& M. BLACK, (1966), Translations from the Philosophical Writings of Gottlob Frege, Oxford, Basil Blackwell.

GEUSS Raymond, (2014), A World without Why, Princeton, Princeton University Press.

GORMAN Jonathan L., (1982), The Expression of Historical Knowledge, Edinburgh, Edinburgh

University Press.

GORMAN Jonathan L., (1991), “Some Astonishing Things," Metaphilosophy 22, 28-40.

GORMAN Jonathan L., (1998 [1974]), “Objectivity and Truth in History,” in Fay B., Pomper P., \&

Vann R. T., (eds.), History and Theory: Contemporary Readings, Oxford, Blackwell.

GORMAN Jonathan L., (2008), Historical Judgement: The Limits of Historiographical Choice, Montréal, McGill-Queen's University Press.

GORMAN Jonathan L., (2011), "The Presuppositions of Writing the History of Historiography," Storia della storiografia 59-60, 198-208.

GORMAN Jonathan L., (2013a), "The Limits of Historiographical Choice in Temporal Distinctions," in Lorenz C., \& Bevernage B., (eds.), Breaking Up Time: Negotiating the Borders between Present, Past and Future, Göttingen, Vandenhoeck \& Ruprecht.

GORMAN Jonathan L., (2013b), "Hayden White as Analytical Philosopher of Mind," Rethinking History: The Journal of Theory and Practice 17, 471-91.

GORMAN Jonathan L., (2014), "History as fiction: the pragmatic truth," in Macfie A. (ed.), The Fiction of History, Abingdon, Oxon, \& New York, NY, Routledge, 13-30.

GORMAN Jonathan L., (2016), "Legal Consciousness: A Metahistory,” in Del Mar M., \& Cobban M. (eds.), Law, Theory and History: New Essays on a Neglected Dialogue, Bloomsbury, Hart Publishing. HEMPEL C. G., (1942), “The Function of General Laws in History,” Journal of Philosophy 39, 35-48. HUME David, (1754), The History of Great Britain, in six volumes, various publishers.

KANT Immanuel, (1784), “Beantwortung der Frage: Was ist Aufklärung?,” various publishers.

KANT Immanuel, (1953 [1783]), Prolegomena: to any Future Metaphysics that will be able to present itself As A Science, Lucas P. G. (trans.), Manchester, Manchester University Press.

KANT Immanuel, (1959 [1784]), "Idea of a Universal History from a Cosmopolitan Point of View," in Gardiner P. (ed.), Theories of History, New York, The Free Press.

KUHN Thomas S., (1962), The Structure of Scientific Revolutions, Chicago, The University of Chicago Press.

KUUKKANEN Jouni-Matti, (2015), Postnarrativist Philosophy of Historiography, Basingstoke, PalgraveMacmillan.

MACBETH Danielle, (2014), Realizing Reason: A Narrative of Truth and Knowing, Oxford, Oxford University Press.

MINK Louis O., (1966 [1965]), “The Autonomy of Historical Understanding," in Dray W. H. (ed.), Philosophical Analysis and History, New York, Harper and Row. 
NAGEL Ernest, (1961), The Structure of Science: Problems in the Logic of Scientific Explanation, London, Routledge and Kegan Paul.

POMPA Leon, (2002), (ed. and trans.), Vico: The First New Science, Cambridge, Cambridge University Press.

POPPER K. R., (1945), The Open Society and its Enemies, vol. 1, Plato, and vol. 2, Hegel and Marx, London, Routledge and Kegan Paul.

POPPER K. R., (1961), The Poverty of Historicism, 2nd edition, London, Routledge and Kegan Paul. QUINE W. V. O., (1960), Word and Object, New York, John Wiley and Sons.

QUINE W. V. O., (1961 [1951]), “Two dogmas of empiricism”, in his From A Logical Point of View, 2nd edition, New York, Harper and Row, 20-46.

QUINE W. V. O., (1990), Quiddities: An Intermittently Philosophical Dictionary, London, Penguin. RORTY Richard, (1982), The Consequences of Pragmatism, Minneapolis, University of Minnesota Press.

Rотн Paul A., (2016), "Back to the Future: Postnarrativist Historiography and Analytic Philosophy of History," History and Theory 55, 270-81.

scotT Walter, (1910), The Abbot: Being a Sequel to the Monastery, London, Henry Frowde, Oxford University Press.

SKINNER Quentin, (1969), "Meaning and Understanding in the History of Ideas" History and Theory 8, 3-53.

SPENCER Mark G., (2013), David Hume: Historical thinker, Historical Writer, University Park, PA, Penn State University Press.

STRAWSON P. F., (1959), Individuals: An Essay in Descriptive Metaphysics, London, Methuen.

STRAWSON P. F., (1971), "Intention and Convention in Speech Acts," in Searle J. R. (ed.), The Philosophy of Language, London, Oxford University Press.

TAYLOR A. J. P., (1965), English History 1914-1945, Harmondsworth, Penguin.

TUCKER Aviezer, (2004), Our Knowledge of the Past: A Philosophy of Historiography, Cambridge, Cambridge University Press.

VASARI Giorgio, (1550), Lives of the Most Excellent Painters, Sculptors, and Architects, various publishers.

VILLA Dana, (2013), "The Legacy of Max Weber in Weimar Political and Social Theory," in Gordon P. E., \& McCormick P. E. (eds.), Weimar Thought: A Contested Legacy, Princeton, NJ, Princeton University Press.

WALSH W.H., (1951), Introduction to Philosophy of History, London, Hutchinson.

WHEWELL William, (1840), Philosophy of the Inductive Sciences, founded upon their History, various publishers.

WHITE Hayden V., (1973), Metahistory, Baltimore, Johns Hopkins University Press. WHITE Morton G., (1965), Foundations of Historical Knowledge, New York, Harper and Row. WINCH Peter, (1958), The Idea of a Social Science and its Relation to Philosophy, London, Routledge and Kegan Paul. 


\section{NOTES}

1. See, for example, White 1965.

2. Quine's entire oeuvre is evidence for this. He did, however, display a fondness for etymology. See Quine 1990, where the alphabetically ordered entries jump from "Gödel's Theorem" to "Ideas" with no mention of "History," "Future" has a place, with a rare (for Quine) reference to an ethical issue (74-5); "Past," "Present" and "Time" do not appear. The entry for "Etymology" is entirely in the present tense, although see the entry for "Kinship of Words" for a historical conjecture.

3. Strawson (1959: 117). I have presented arguments relating to this quotation in Gorman 2008 and in Gorman 2016.

4. Here Strawson, and we too for the present, assume that the derivation of historical assertions from historical evidence involves different skills and considerations from those characteristic of the discipline of philosophy

5. This is an observation made about analytical philosophers in general, and not particularly about Strawson.

6. Just because some past philosopher wrote that he or she was a "pragmatist" does not mean that they were, nor that denying it meant that they were not. Peirce famously suggested that he was a "pragmaticist" rather than a "pragmatist" (Gallie 1966: 22), while Engels reported in 1890 that Marx had said he was not a Marxist.

7. Analogously, that philosophy was not fundamentally distinct from a social science was the main point made in Winch 1958.

8. "Context" is a shockingly ambiguous term. I address some of its features in Gorman 2016.

9. understanding 'context' as including a range of things, including the context of other sentences or a time-extended dialogue or discourse which arose under certain social conditions.

10. Ewing 1935. However, for a famous exception among historians see Skinner 1969.

11. See, however, Macbeth 2014.

12. Winch 1958.

13. Strawson (1971: 24). Emphases in the original.

14. Austin 1971.

15. See Gorman 2011.

16. Is the "world of mathematical ideas" part of this world? Following Plato, perhaps not, but we can suspend judgement about how far we can agree here with Plato. Nevertheless, mathematics raises special problems that will not be deal with in the present context. Again, see Macbeth 2014.

17. Recall Quine's pragmatic conception that philosophy and science are continuous with each other: Quine 1961. It seems sure that Quine did not think of himself, a philosopher and logician, as tolerating science; by contrast, scientists might well, in so far as they accepted his approach, think of themselves as having to tolerate philosophy.

18. See Gorman 2011.

19. See Gorman 2014.

20. "It must be laid down that a letter retains in a given context the meaning once given to it" (Geach \& Black 1966: 1).

21. "At any given time, in any given place, there will be a set of conditions - social, historical, meteorological, physiological - that will ensure that a word uttered in that place and at that time will have a meaning different than it would have under any other conditions," (Bakhtin 1981: Glossary ,428). 
22. Recall Strawson's distinction between "descriptive" and "revolutionary" metaphysics in Strawson (1959: 9). Thomas S. Kuhn had a revolutionary take on meaning in Kuhn 1962; as did Paul K. Feyerabend in Feyerabend 1968 and Feyerabend 1975.

23. Bradley (1922: 597). Bradley did not think of himself as a pragmatist, and excludes "practice" from his concerns in that work, Bradley (1922: 17-9 and passim).

24. Bradley (1922: 640). Contrast this with his view in Bradley (1874: 9): “The historical event [...] involves in the first place a judgment. It is 'objective,' it is distinguished in itself, and yet it is a whole."

25. Mink (1966: 180-1).

26. Bradley (1922: 95).

27. Bradley (1922: 1).

28. Bradley (1922: 1).

29. Pragmatism, it has been so often said, is what "works," but that, it has also been so often said, is not much help.

30. I am able now (2016) to characterise or re-describe my ideas in 1970 in a way I did not know, or perhaps could not have known, at the time and will where appropriate do so. I will, in other words, use on occasion what Danto (1965: 152 and generally chap. VIII) called "narrative sentences." His example is "The Thirty Years War began in 1618," which one could not have known in 1618. Such sentences describe an earlier event in terms which involve referring to a later event not knowable at the earlier time, although we need not limit this to "referencing" or to "events." Whatever the detail about that, only hindsight enables these to be constructed.

31. This was at Peterhouse, Cambridge, famous at the time for the quality of its historians. My supervisors were officially Bryce Gallie and Mary Hesse, but among historians Maurice Cowling took a lead and I found Ian Hacking helpful also.

32. Gorman 1991.

33. Expelled by Plato, too. Walsh (1951: 12).

34. Hume 1754, dominant for decades.

35. Burrow 2007.

36. See, for example, Spencer 2013.

37. He famously admitted to being woken from his dogmatic slumber by David Hume, Kant (1953:

9).

38. "We can regard the history of the human race as the progressive realisation of a rational plan of nature to bring about a perfect moral community with a perfect political constitution. We, being rational, can work out this plan, and so help forward our necessary progress towards that final perfect state" (Kant 1959: 22-34).

39. Gallie (1966: 28-9), with reference to CP 5.189.

40. Helped by my teachers Leon Pompa and W. H. Walsh.

41. Walsh (1951: 15ff).

42. Danto (1965: chapter 1).

43. The assumption that there is a "meaning of history" to be found, particularly an ethical one, is dubitable. See Geuss 2014.

44. This is a helpfully brief summary from Villa (2013: 89). For the original, see Pompa 2002, where two other characteristics of Vico's position are summarised and worth mentioning here: it "challenges the traditional view that philosophy can lay claim to a historically independent viewpoint," while the New Science was written to demonstrate in practice "his conception of the philosophical importance of etymology" (endpaper).

45. Popper 1961 and Popper 1945.

46. Gardiner 1952. Gardiner was one of my 1973 Cambridge Ph.D. examiners. The other was Quentin Skinner.

47. Walsh (1951: 11ff). 
48. Various works including Collingwood 1946.

49. Various works including Bradley 1874.

50. Butterfield 1931.

51. Unless the historian were a historian of science like Kuhn, but no "proper" historian I knew would have accepted him as a member of their discipline. Reflection on Kuhn's work required philosophy of science, not philosophy of history.

52. It took a while for a distinctive contribution to be made here: Bayesian decision theory was offered in Tucker 2004.

53. Hempel 1942.

54. Dray 1957.

55. Gallie 1964.

56. Danto 1965.

57. White 1965.

58. See, for example, Davidson 1968.

59. Danto (1965: chap. VIII). Danto's subsequent career as a philosopher of aesthetics and art critic almost proved the point, historically if not philosophically. Pragmatically, I here forget undergraduate philosophical warnings that one should not engage in ad hominem reasoning.

60. After I left Cambridge I became aware of White 1973, in which aesthetics played an epistemic role. It would not have helped me if I had known of such material in 1970, as I explain in Gorman $2013 b$.

61. Kuhn 1962; Quine 1961; Quine 1960; Feyerabend 1968.

62. Hempel acknowledged the merits of Kuhn's history-based philosophy of science when he gave his paper "Problems in the empiricist construal of theories" ["not to be quoted in print"] at a History and Philosophy of Science Seminar, Cambridge, 4th November 1971.

63. "History, Religion, and Freedom in the Thought of Herbert Butterfield, Michael Oakeshott, and Maurice Cowling," September 2016.

64. See, for example, Edmonds \& Eidinow 2001. Such "threats" are rare enough in philosophy to warrant a book. We might well be flooded with such books about historians, if it were thought to be a matter of comment.

65. Taylor 1965.

66. The Times report, 18th September 1945.

67. Taylor (1965: Note B, 647-8).

68. Taylor (1965: 648).

69. Bradley (1922: 640).

70. I stress this, as "context," earlier noted as ambiguous, is here limited in its reference, and does not refer to other notions of "context," and in particular not to what some historians mean by it as the "religious, political, and economic factors" involved. See Skinner 1969.

71. Developed for my PhD thesis, the construction is explained in Gorman 1998, where many other constructions permitted the investigation of associated problems. I argued for the need to recover the rational standards which would have to be involved to make sense of the "objectivity" or "comparative objectivity" of selection in historical accounts. Further lengthy analysis of these matters was given in Gorman 1982, which used Michael Dummett's understanding of antirealism.

72. Scott (1910: xi). I say more about this in Gorman 2014.

73. Particularly relevant might be Hempel's deductive-nomological model of causal explanation.

74. Bradley's view in 1874 was: “[...] it is clear to us that we are concerned with a number of judgments, [...] it is not less clear that these many judgments are united, and, as it were, resolved in a single judgment which answers to the whole event. This one judgment comprehends in itself the many judgments; it must be looked on as their result, or in other words it is a conclusion." (Bradley 1874: 9-10). See, for later work on the argumentative structure of historiography, 
Kuukkanen (2015: 86-96, 157-67). His is in many ways a pragmatic position $(65-6,138-47)$. See Roth 2016.

75. Nagel (1961: 580-1 and note 25).

76. Gorman (1998: 331).

77. Gorman 1998.

78. Quine (1961: 42). I began to follow through this material in Gorman 1982 and in Gorman 2008.

79. I asked Quine in about 1974 why he assumed the "science" which he took to be continuous with his philosophy was physics or psychology and not sociology, but got no useful answer. That it might be history rather than social science seemed to be one thought too far, and I did not mention it to him.

80. Rorty 1982.

81. Berlin (1980: 115). Berlin continued here, "It is this network of our most general assumptions, called commonsense knowledge, that historians to a greater degree than scientists are bound, at least initially, to take for granted."

82. Quine (1961: 43).

83. Quine (1961: 43).

84. Quine (1961: 42).

85. This is in effect Quine's argument against the analytic-synthetic distinction given in Quine 1961. In practice rather than principle there are limitations - often strong limitations - on the available room for adjustment, limitations that a pragmatic approach can recover. Moral beliefs, in so far as they can be held true (for expressivism might be the best explanation here), have the same status as factual beliefs on this approach, and equally permit unlimited adjustment in principle. It follows that there is no empirical warrant for the fact-value distinction, and thus, again given empiricism, no epistemological justification for that distinction. Quine himself does not consider questions of value, however.

86. Quine (1960: 68ff and passim).

87. Quine (1961: 43).

88. Gorman (1998: 327).

89. Bradley (1922: 640).

90. Quine (1960: 91). "Learn" here does not mean "discovering," for our concepts have to be created, often on the basis of lengthy, even aesthetic, experience.

91. See Gorman 2013a and Gorman 2011.

92. Hence the title of my first book, Gorman 1982.

93. Austin (1962: 8).

94. Cornford (1908: 14).

95. The idea comes from Whewell 1840, and is used by Walsh to speak of the historian's search for "dominant concepts" by which to "illuminate his facts." Walsh (1951: 24ff and 61). See also Mink 1966 and Kuukkanen (2015: chap. 6).

96. Vasari 1550.

97. Kant 1784.

98. See Gorman 2011. 


\section{ABSTRACTS}

I present the history of philosophy, and history more generally, as a context of ideas, with respect to which philosophers and historians share concerns about the meaning of the texts they both use, and where for some there is a principled contrast between seeing meaning in quasimathematical terms ("a philosophical stance") or in terms of context ("a historical stance"). I introduce this imagined (but not imaginary) world of ideas as temporally extended. Returning to my early research into the epistemic problems of historiography, I present my view that foundational was meaningful language in a shared world, and I display some difficulties found in handling the "wholeness" of historical accounts. I came to realise that it was epistemic opposition between historical accounts that mattered. I concluded that analytical philosophy was wrong to assume that individual sentences were free-standing meaningful units that could be juxtaposed with others at whim, and that an understanding of the rational grounds for determining relevance was needed. In order to make sense of this I used Quine's conception of the "web of belief," and noted that a historical account could be treated as a "unit of empirical significance" in his terms. I observe that, although the epistemic problems of history arose for me before I considered his pragmatic position, nevertheless attention to those problems required me to adopt the Quine-based form of pragmatism I describe. I came to realise that I had wrongly adopted a synchronic view of the Quinean web, thereby adopting a "philosophical stance." Rather, the web should be conceived in diachronic terms as a rolling web, so forming history itself. It is wrong to think that language started in atomistic terms so that, following Aristotle, it first consisted of simple concepts forming sentences of brief and narrow subject-predicate form. Instead, early communications took the form of oral traditions usually in narrative form. Meaningful wholes such as historical accounts are conceptually prior to atomistic sentences and need to be seen in extended temporal terms, so that an Aristotelian subject-predicate metaphysics is implausible. Quine's pragmatism framed and facilitated my historical stance despite the unashamed philosophical stance that he adopted.

\section{AUTHOR}

\section{JONATHAN GORMAN}

Queen's University Belfast

jonathan.gorman[at]cantab.net 